\title{
Public Debt and Domestic Private Investment: A Crowding Effect in Nigeria
}

\author{
Charity I. Anoke ${ }^{1}$, Stephen I. Odo, Ph.D ${ }^{2}$, Bernard E. Nnabu, Ph.D ${ }^{3}$ \\ ${ }^{1,3}$ Department of Economics, Ebonyi State University, Abakaliki \\ ${ }^{2}$ Department of Economics, Godfrey Okoye University, Nike, Enugu \\ Corresponding Author*
}

\begin{abstract}
This study investigated the relationship between public debt and domestic private investment in Nigeria from 1980 2018. The objectives of the study are: determine the extent to which external debt significantly impacts on domestic private investment in Nigeria, examine if there is any significant impact of domestic debt on domestic private investment in Nigeria; ascertain the extent at which debt servicing significantly impact on domestic private investment in Nigeria and explore if there is any significant causal relationship between public debt and domestic private in Nigeria. The paper applied the following statistical and econometric tests: stationarity test, co integration test, VECM test and VEC Granger causality. Results indicated that external debt has negative significant impact with domestic private investment, domestic debt has negative significant effect on domestic private investment. Debt servicing has a negative insignificant impact on domestic private investment. And there is no directional causality between public debt and domestic private investment. Some of the implications of the results is significant unproductive influence of public debt on domestic private investment, as such most borrowed fund are not invested in choice investment. Sourcing fund for private investment is compromised by high level of government involvement in loanable fund, meaning that since domestic borrowing is mostly done by government due to their trusted repayment plan, domestic private investors will be left with unattainable or difficult conditions that will not allow access to those credit facilities. The researcher concluded that public debt crowds out domestic private investment in the long run in Nigeria within the period of the study.
\end{abstract}

Keyword: External Debt, Domestic Debt, Private Investment, crowding out, Debt Servicing

\section{INTRODUCTION}

$\mathrm{D}$ eveloping countries are known for debt dynamics than the developed ones. The stages of growth and development theory of Rostow (1960) in developing countries most times witnesses position where debt levels have positive link with their growth levels.

Public debt is an important measure of bridging the financing gaps of the government. Prudent utilization of public debt leads to higher economic growth and adds to capacity to service and repay external and domestic debt. It also helps the government to accomplish its social and developmental goals, (Bonga, Chirowa, \& Nyamapfeni, 2015). Hansen (1941) also declares that, "Public debt is an essential means of increasing employment and has become an instrument of economic policy today. Harold (1943) maintains that, "Public debt is a national asset rather than liability and it is essential for the economic prosperity of the country". Harold (1958) further explains that, "for every debtor there is also a creditor, it follows that the existence of an internally held national debt in and of itself will not impoverish a nation as debtors than it will enrich it as creditors. Public debt is a measure of government indebtedness, comprising of domestic and external debt. Each of these types of debt has its own benefits and drawbacks, with a trade-off between costs of borrowing and exposure to various types of risks that needs to be balanced in order to ensure ample and timely access to cost efficient funding.

Onboarding the public debt portfolios, we discussed domestic debt as a charge on budget and must be serviced through government revenues and/or additional borrowings whereas external debt (both public and private) is a charge on balance of payment and must be serviced from foreign exchange earnings, reserve drawdown, and additional borrowings. According to Jorge (2020), external debt might affect economic growth differently among countries. Government borrowing through domestic sources is vital in stimulating investment and private savings, as well as strengthening domestic financial markets, since it provides liquidity to the markets, if properly utilized. According to Rana and Abid (2009), within thin financial markets and poor debt management, expansion in domestic debt would pose significant negative implications for private investment, fiscal sustainability and ultimately economic growth.

Therefore, the two should be managed separately to ensure fiscal and external account solvency. Domestic debts are debt instruments issued by the federal government and denominated in local currency. A country encounters debt problem if debt servicing capacity is not commensurate with sustainable level of the economy. Unsustainable levels of debt have repercussions for an economy in the form of a re-allocation of resources towards debt servicing; as the servicing of domestic debt has severely encroached on resources available for socio-economic development and poverty alleviation. Nigeria's domestic debt has been rising over the years (DMO, 2016). Interestingly, diverting society's limited capital from productive private to unproductive public sector, retards the private sector and the economy at large. 
The relationship between government borrowing and private investment is a perennial issue in economic growth and development judging from several theoretical and empirical scholarly papers that have been written to conceptualize if government borrowing leads to crowding out or crowding in. Soludo (2003) asserted that a nation borrows massively either to increase investment or increase consumption. Depending on how the borrowed fund is utilized, public debt can make or mar an economic growth.

\subsection{Statement of Research Problem}

Historically, in Nigeria, like so many other developing countries, public expenditure has recorded a continuous increase over time, especially, as the government assumes an active role in the development of the economy by trying to put in place the infrastructure and institutional superstructure necessary for economic growth and development. Due to narrow tax base, increasing budgetary expenditures and falling crude oil price at the international oil market, the Nigerian economy has been confronted with declining growth of revenue for several decades; forcing the Nigerian government to rely on continuous borrowing both from internal and external sources to finance the budgetary deficit. The enormous debt stock and huge debt service payments for Nigeria distorts volumes of domestic investment, which has the tendency to boost economic growth and development as observed by Clement et al. (2003).

Between 1980 to 2004, domestic and external debt with domestic private investment maintained inconsistent trend, but obviously noticed from the statistics that private investment suffered impediment from both domestic and external debt. This means that public debt portfolios crowds out private investment, that is, increase in public debt led to reduction or non-existence of private investments. However, within 2005 and 2007, there was increase in domestic debt as well as domestic private investment. The later situation is contrary to the apriori expectation, but could be explained by the debt forgiveness received from Paris Club within the stated period. Also, domestic private investment remained in decline over the years, even when either domestic or external declined. This calls for further investigations on why such occurrences.

Nigeria, therefore, has witnessed rising public debt profile since independence in 1960 to date, even when she obtained debt forgiveness from the Paris Club Consortium in 2005. For instance, Nigeria's total government debt grew from N13.526 billion in 1981 to N69.892 billion in 1986 and increased further to N960.994 billion in 1996. The increasing trend was significantly sustained between 1998 and 2004 as total government debt increased to N1.170 trillion in 1998, N3.995 trillion and N6.260 trillion in 2000 and 2004 respectively. The value of government debt dropped to N4.220 trillion in 2005 and further declined to N2.204 trillion in 2006 (mainly as a result of the debt forgiveness granted to Nigeria by the Paris Club consortium in 2005). However, total debt outstanding resumed its incremental curve afterwards as government total debt stood at N3.818 trillion, N7.554 trillion, N12.604 trillion and N17.360 trillion in 2009, 2012, 2015 and 2016 respectively. This figure has risen to N19.639 trillion as at June 30, 2017, with a total domestic debt outstanding at N15.037 trillion making up the total public debt outstanding, (CBN, 2015); (DMO, 2017). In 2018, public debt kept increase to the tune of N24.387, DMO (2018).

Despite the debt forgiveness and tranches of the Paris Club fund released up to 2018 and greater part of the money in the previous years, external debt of the country is still on a rise. This implies that options of reducing public debt and increasing investments is not yet achieved, placing much debt burden on the domestic economy. To this end, the study investigated the relationship between public debt and domestic private investment with the lens of crowding out effect analysis in Nigeria within the period of 1980 and 2018.

\subsection{Objective of the Study}

The main objective of this study is to investigate the relationship between public debt and domestic private investment in Nigeria. The specific objectives are to:

1. Determine the extent to which domestic debt affect domestic private investment in Nigeria within the period of study.

2. Investigate if there is any significant impact of external debt on domestic private investment in Nigeria within the period of study.

3. Ascertain the extent to which debt servicing significantly impact on domestic private investment in Nigeria within the period of study.

4. Explore if there is any significant causal relationship between public debt and domestic private investment in Nigeria within the period of study.

\section{Significance of the Study}

The need for this study cannot be overemphasized. It has direct or indirect significance as the relationship between external debt and investment has a great influence on the pace of growth in a developing or developed country. This work reveals the magnitude and nature of impact that external and domestic debt can exert on private investment, serving as a guide to the government borrowing policies, and likewise to foreign investors regarding making direct investment decisions. It enriches the existing literature on external debt and domestic investment in developing economies and provide reference on the relationship for future studies.

\section{LITERATURE REVIEW}

This section looked at public debt from different theories and empirical works.

\subsection{Theoretical Review}

The link between public debt and private investment can be analyzed through the effect of fiscal deficit on investment, 
explained by "debt overhang", "crowding out" effect, for emphasis

\subsubsection{Debt Overhang Theory}

Debt overhang indicates a situation in which a firm's debt is so large that any earnings generated by new investment projects are entirely appropriated by existing debt holders, even projects with a positive net present value cannot reduce the firm's stock of debt or increase the value of the firm (Myers, 1977). A debt overhang serves to dissuade current investment, since all earnings from new projects would only go to existing debt holders, leaving little incentive and ability for the entity to attempt to dig itself out of the hole. It can distress entities in different ways: cause companies and countries to put a pause on further spending and/or investment, leading to underinvestment, Krugman (1988).

Therefore, when a country suffers from debt overhang, debt relief has the potential to improve economic efficiency. This can be possible by reducing the debt stock; the reduction will then spill-over its effects and reduce the debt overhang. To help in facilitating growth debt relief frees resources which were tied up in debt servicing enabling government to reallocate the freed resources to more productive areas.

\subsubsection{Crowding Out Effect of Public Debt in Nigeria}

One channel of crowding out is a reduction in private investment that occurs because of an increase in government borrowing. The macroeconomic theory behind crowding out provides some useful intuition, that is, an increase in the demand for loanable funds by the government (e.g. due to a deficit) shifts the loanable funds demand curve rightwards and upwards, increasing the real interest rate. A higher real interest rate increases the opportunity cost of borrowing money, decreasing the amount of interest-sensitive expenditures such as investment and consumption. Thus, the government has "crowded out" investment. Classical economists like Smith (1776) opined that crowding -out effect is a major significant factor, but Keynesian economists argued that the multiplier effect outweighs any potential negative impacts resulting from the crowding out of private sector activity. This is the appropriate theoretical framework at which this paper is anchored on, justified by the topic, an investigation of the crowing out effect of public debt on private investment. This paper stands to contest the theory that some positive economic acceleration could make this theory not to be effective in most scenarios, like, if the borrowed fund is productively used through circular flow, instead of crowd out, it could crowd in private investment.

\subsection{Empirical Review}

Different views on the impact of public debt on investment in the literatures exist, while some support the crowding-out effect, others argued that it is actually crowding-in effect. Jorge (2020) assessed the effect of the Portuguese external debt from 1999-2019 with quarterly data. Their result indicated that public external debt increased public investment, while private external debt damaged private investment. The author concentrated on the effect of external debt on private investment; while this paper went further to investigate the effect of both external and domestic debt on private investment. Salyungu and Felician (2019) explored the effect of public debt on private investment in Tanzania using secondary data for the period of 1970-2016 and Autoregressive Distributed Lag (ARDL) bound test to cointegration. Their results suggested combined effect of domestic and external debt on private investment which is statistically significant both in long run and short run. This paper filled the gap in scope of study to update the current literature up to 2018.

Adetokunbo and Ebere (2019) delved into an empirical investigation on determinants and analysis of domestic debt in Nigeria from 1970 to 2015 using data from Central Bank. Findings suggested that there exist bi-directional granger causalities between domestic debt and budget deficit, domestic debt and external debt and domestic debt and GDP growth rate. The research differs from the author in terms of scope, while the author concentrated on domestic debt and budget deficit, this paper delved into details of impact of both domestic and external debt on domestic private investment.

Onyinyechi (2019) considered the consequences of external loan on capital investment in Nigeria (1996 - 2018), employing data from the World Bank and Central Bank of Nigeria Statistical Bulletin, 2018 with variables as, government capital expenditure, external debt accumulation, debt servicing cost, inflation rate, and exchange rate. The author used the ordinary least squares multiple regression method. The regression results indicated that external debt has a significant negative impact on capital investment while debt servicing cost has a strong and significant positive effect on capital investment. The author generally considered consequences of external debt on capital investment, but this research streamlined the aspect of investment that suffers as external debt is incurred and inefficiently used.

The reviewed studies have not reached a consensus on the actual relationship between public debt and domestic private investment, owing to their differences in views, scope, the specification of econometric models, and the selection of variables, variations in the results and interpretation. While majority of the reviewed works emphasized public debt and economic growth, the study concentrated on public debt and domestic private investment; using disaggregated public debt portfolios (domestic and external debt) in Nigeria from 1980 2018, considering crowding out effect. The gaps in literature are explained in details as refers above;

This study differs from other works in terms of variables like, External Debts and GDP by Ezema, Nwekwo and Agbaji (2018), Adetokunbo (2019), Salama and Aziza (2018), Murungi and Okiro (2018), Ncanywa and Masoga (2018), Charles and Abimbola (2018); Onakoya and Ogunade (2017). Other studies investigated domestic and external debt with 
foreign direct investment and private credits, like, Emenike (2015), Philip et al (2017) and Mba et al (2016). Interest rate, government expenditure and private investment were examined by Adeyemi et al (2018) and Inimino, Abuo and Bosco (2018) to mention but a few.

Specifically, Joshua (2019) specified equations that are not directly addressing the topic of study without justification. This misapplication will be corrected by this study using domestic private investment variable and data as generated from the statistical bulletin. He also claimed that public debt crowds out public investment instead of private investment, Nwaeze (2017) joined in this claim. In the study of Ncanywa and Masoga (2018), public debt and public investment was considered, as this study focused on public debt and domestic private investment; emphasizing on crowding out effect. Mentioned here are most of the reviewed work done in other countries by the following authors, Thilanka and Ranjith (2018) - Sri Lanka, King'wara (2014) - Pakistan, Bista (2013) - Nepal and Salyungu and Felician (2019) did a study in Tanzania. Example, Caspah (2018) investigated on Kenya experience within 1975 to 2014, while this study examined public debt and domestic private investment in Nigeria from 1980 to 2018. In terms of methods, Salyungu and Felician (2019) used a wrong method of ARDL for variables integrated of order one, 1(1). Ncanywa and Masoga (2018), should have used VAR Granger causality since the researchers employed ARDL approach for data estimation. The unit root result was missing in the paper, which should inform the type of estimation techniques to be used.

\section{METHODOLOGY}

The study employed Expost facto research design. Granger causality technique was used to test the causal relationship among the variables, Granger causality by Granger (1969) shows whether a change in a variable will cause a change in another variable, this can be unidirectional, bidirectional or no relation at all based on the probability value of the F-statistics. While the data used spanned from 1980 to 2018 and vector error correction mechanism employed for model evaluation with the use of E view 9.0 and 10 analytical tool. The theoretical framework for the study is the crowding-out effect hypothesis that depicts a situation where increased government borrowing leads to a reduction in domestic private investment. This can be functionally written as;

$$
\mathrm{DPINV}=\mathrm{f}(\mathrm{PD})
$$

We disaggregated the components of public debt into external and domestic debt, to generate a functional form, thus;

$$
\text { DPINV }=\mathrm{f}(\mathrm{EXD}, \mathrm{DMD}) \ldots \ldots \ldots \ldots \ldots
$$

We incorporate debt servicing since it has long run impact on domestic private investment, as stated below:

$$
\text { DPINV }=\mathrm{f}(\text { EXD, DMD,TDSV }) .
$$

To accommodate control variables that have the capacity to influence the dependent variable, we specified:

$$
\text { DPINV }=\mathrm{f}(\text { EXD, DMD, TDSV, NINT, FDI }) .
$$

where DPINV = Domestic private investment, $\mathrm{EXD}=$ external debt, DMD means domestic debt, NINT is Interest rate, FDI means foreign direct investment, TDSV is total debt servicing.

The variables are transformed into log linear form as:

$\log \mathrm{DPINVt}=\beta 0+\beta 1 \log \mathrm{EXDt}+\beta 2 \log \mathrm{DMDt}+\beta 3 \log \mathrm{TDSVt}$ $+\beta 4 \operatorname{logNINTt}+\beta 4 \operatorname{logFDIt}+\mathrm{e}_{\mathrm{t} . . .}(5)$

where the variables are explained above, $\beta 0-\beta 4$ are parameters of estimation and $e_{t}$ is the error term. All the variables are using the same unit of measurement being in logarithm form, this is allowed to remove outliers.

\section{RESULT AND DISCUSSION}

This segment is centered on the result for data analysis which involves working to discover patterns and trends in data sets while interpretation involves explaining those patterns and trends. The study began with the test of unit root to determine the stationarity of all the employed variables using Augmented Dickey Fuller (ADF) unit root test. The tests were conducted to avoid spurious regression.

\subsubsection{Unit Root Test}

The study began with the test of unit root to determine the stationarity of all the employed variables using Augmented Dickey Fuller (ADF) unit root test. The tests were conducted

\begin{tabular}{|c|c|c|c|c|c|c|}
\hline Variables & Level & $\begin{array}{c}5 \% \text { crt.va } \\
1 \\
\end{array}$ & Pval. & 1 st diff & $\begin{array}{c}5 \% \\
\text { crt.val }\end{array}$ & Pval. \\
\hline $\begin{array}{c}\text { LOGDPIN } \\
\mathrm{V}\end{array}$ & $\begin{array}{c}- \\
2.7685 \\
1\end{array}$ & $\begin{array}{c}- \\
3536601\end{array}$ & $\begin{array}{c}0.217 \\
2\end{array}$ & $\begin{array}{c}- \\
4.0451 \\
1\end{array}$ & $\begin{array}{c}- \\
3.54032 \\
8\end{array}$ & $\begin{array}{c}0.015 \\
9\end{array}$ \\
\hline LOGEXD & $\begin{array}{c}- \\
2.3516 \\
9\end{array}$ & $\begin{array}{c}- \\
3536601\end{array}$ & $\begin{array}{c}0.397 \\
4\end{array}$ & $\begin{array}{c}- \\
6.2493 \\
8\end{array}$ & $\begin{array}{c}- \\
3.54032 \\
8\end{array}$ & $\begin{array}{c}0.000 \\
0\end{array}$ \\
\hline LOGDMD & $\begin{array}{c}- \\
1.3736 \\
3\end{array}$ & $\begin{array}{c}- \\
3536601\end{array}$ & $\begin{array}{c}0.852 \\
3\end{array}$ & $\begin{array}{c}- \\
4.4303 \\
1\end{array}$ & $\begin{array}{c}- \\
3.54032 \\
8\end{array}$ & $\begin{array}{c}0.006 \\
1\end{array}$ \\
\hline LOGDSV & $\begin{array}{c}- \\
2.5566 \\
6\end{array}$ & $\begin{array}{c}- \\
3536601\end{array}$ & $\begin{array}{c}0.301 \\
1\end{array}$ & $\begin{array}{c}- \\
4.8251 \\
7\end{array}$ & $\begin{array}{c}- \\
3.54032 \\
8\end{array}$ & $\begin{array}{c}0.002 \\
2\end{array}$ \\
\hline LOGFDI & $\begin{array}{c}- \\
1.8312 \\
2\end{array}$ & $\begin{array}{c}- \\
3536601\end{array}$ & $\begin{array}{c}0.669 \\
1\end{array}$ & $\begin{array}{c}- \\
5.4710 \\
1\end{array}$ & $\begin{array}{c}- \\
3.54032 \\
8\end{array}$ & $\begin{array}{c}0.000 \\
4\end{array}$ \\
\hline NINT & $\begin{array}{c}- \\
2.5098 \\
1\end{array}$ & $\begin{array}{c}- \\
3536601\end{array}$ & $\begin{array}{c}0.321 \\
9\end{array}$ & $\begin{array}{c}- \\
6.7677 \\
8\end{array}$ & $\begin{array}{c}- \\
3.54032 \\
8\end{array}$ & $\begin{array}{c}0.000 \\
0\end{array}$ \\
\hline
\end{tabular}
to avoid spurious regression. The results of the test are presented in table 1 below.

Table 1: Augmented Dickey - Fuller Unit Root Test Result

Sources: Author's computation, 2020 using E view 10

From table 1 above, the variables, external debt (EXD), Domestic debt (DMD), Debt Servicing (DSV), Interest rate (NINT) and Foreign direct investment (FDI) are of 1(I) order of integration, meaning that at levels, the variables were not stationary (low coefficient and insignificant Pval.), but became stationary at first difference (higher coefficient with 
significant Pval.). This necessitated the use of Johansen Co integration approach.

\subsubsection{Co-integration Test}

The result is to ascertain the evidence of the long run relationship among the variables that were tested.

Table 2: Unrestricted Cointegration Rank Test (Trace)

\begin{tabular}{|c|c|c|c|c|}
\hline $\begin{array}{c}\text { Hypothesized } \\
\text { No. of CE(s) }\end{array}$ & Eigenvalue & $\begin{array}{c}\text { Trace } \\
\text { Statistic }\end{array}$ & $\begin{array}{c}0.05 \\
\text { Critical } \\
\text { Value }\end{array}$ & Prob.** \\
\hline LOGDPINV * & 0.751380 & 129.9601 & 95.75366 & 0.0000 \\
\hline LOGEXD* & 0.627176 & 79.85422 & 69.81889 & 0.0064 \\
\hline LOGDMD & 0.472095 & 44.33482 & 47.85613 & 0.1031 \\
\hline LOGDSV & 0.270961 & 21.33658 & 29.79707 & 0.3370 \\
\hline NINT & 0.234080 & 9.959569 & 15.49471 & 0.2838 \\
\hline LOGFDI & 0.009928 & 0.359197 & 3.841466 & 0.5490 \\
\hline
\end{tabular}

Source: Author's compilation, 2020, using E view 10

Table 3: Unrestricted Cointegration Rank Test (Maximum Eigenvalue)

\begin{tabular}{|c|c|c|c|c|}
\hline $\begin{array}{c}\text { Hypothesized } \\
\text { No. of CE(s) }\end{array}$ & Eigenvalue & $\begin{array}{c}\text { Max- } \\
\text { Eigen } \\
\text { Statistic }\end{array}$ & $\begin{array}{c}0.05 \\
\text { Critical } \\
\text { Value }\end{array}$ & Prob.** \\
\hline LOGDPINV* & 0.751380 & 50.10590 & 40.07757 & 0.0027 \\
\hline LOGEXD* & 0.627176 & 35.51940 & 33.87687 & 0.0316 \\
\hline LOGDMD & 0.472095 & 22.99823 & 27.58434 & 0.1736 \\
\hline LOGDSV & 0.270961 & 11.37701 & 21.13162 & 0.6097 \\
\hline NINT & 0.234080 & 9.600372 & 14.26460 & 0.2395 \\
\hline LOGFDI & 0.009928 & 0.359197 & 3.841466 & 0.5490 \\
\hline
\end{tabular}

Source: Author's compilation, 2020, using E view 10

In the Johansen co integration test, the trace statistic is used to determine the presence of co-integration among the variables. As observed under unrestricted co-integration rank test and Maximum Eingenvalue, the trace statistics indicated two cointegrating vectors. This is shown by the asterics variables in table 2 and 3 above. This necessitated the use of vector error correction mechanism to test for the effect of explanatory variables on the dependent variable. The long run individual impact of independent variables on dependent variable is analyzed using normalized cointegration equation presented as follows:

DPINV $=4.302-0.109$ LOGEXD -0.214 LOGDMD 0.062 LOGDSV + 0.184LOGNINT -0.724 LOGFDI
$(0.02267)$
$(0.05910)$
$(0.03479)$
$(0.06348)$
$(0.17999)$
$[-4.82212]$

$$
\begin{array}{r}
{[-3.63049]} \\
{[-11.4200]}
\end{array}
$$
[5.29591]

on, 2020, using E view 10

\subsubsection{Vector Error Correction Mechanism}

Having established the existence of the long run relationship among the variables, the study validates the reason for adopting the vector error correction mechanism as econometric method for the estimation. The result of VECM is stated in table 4 below:

Table 4: VECM Result

\begin{tabular}{|c|c|c|c|c|}
\hline & Coefficient & Std. Error & t-Statistic & Prob. \\
\hline ECT (-1) & -0.512567 & 0.103259 & -4.963871 & 0.0001 \\
\hline $\mathrm{D}($ LOG(DPINV(-2))) & 0.222613 & 0.128082 & 1.738046 & 0.0962 \\
\hline $\mathrm{D}($ LOG(EXD(-2))) & -0.119395 & 0.07479 & -1.596404 & 0.1247 \\
\hline $\mathrm{D}($ LOG(DMD(-2))) & 0.016661 & 0.061982 & 0.268807 & 0.7906 \\
\hline $\mathrm{D}(\mathrm{LOG}(\mathrm{DSV}(-2)))$ & 0.015149 & 0.13576 & 0.111587 & 0.9122 \\
\hline $\mathrm{D}(\mathrm{NINT}(-2))$ & 0.036954 & 0.022595 & 1.63548 & 0.1162 \\
\hline $\mathrm{D}($ LOG(FDI(-2)) $)$ & -0.209838 & 0.105469 & -1.989576 & 0.0592 \\
\hline
\end{tabular}

Result in table 4 above confirms the dynamics that existed in the short run with clearly specified probability values. With this approach, the short term and the long term balanced dynamic association existing within the variables under study is established.

Table 5: VEC Granger Causality/Block Exogeneity Wald Tests

\begin{tabular}{|c|c|c|c|}
\hline \multicolumn{4}{|c|}{ Dependent variable: D(LOG(DPINV)) } \\
\hline Excluded & Chi-sq & Df & Prob. \\
\hline $\mathrm{D}($ LOG(EXD)) & 3.349253 & 2 & 0.1874 \\
\hline $\mathrm{D}($ LOG(DMD) $)$ & 0.072914 & 2 & 0.9642 \\
\hline $\mathrm{D}($ LOG(DSV)) & 0.015859 & 2 & 0.9921 \\
\hline $\mathrm{D}(\mathrm{NINT})$ & 3.460616 & 2 & 0.1772 \\
\hline $\mathrm{D}($ LOG(FDI) $)$ & 16.77297 & 2 & 0.0002 \\
\hline
\end{tabular}

Source: Author's Compilation, 2020 using E view 10

In order to examine the possibility of accepting or rejecting hypothesis, we employed estimations of parameters. The study used $5 \%$ as benchmark and critical value for judgments of results. The hypotheses were reported using the long run results.

\section{Decision rule:}

In the Long run, the T-statistics was used in this paper to ascertain the significant level of the tested hypothesis. It is calculated thus:

$\mathrm{N}-\mathrm{k}$

where, $\mathrm{n}$ is the total number of periods of observation and $\mathrm{k}$ the total number of variables tested. So, we have, $38-6=32$. But considering the 2-lag length, we got $38-12=26$.

The $5 \%$ critical value was divided by 2 and we had, 0.025 . The calculated number of tested hypothesis is traced under 0.025 , which resulted to 2.048 level of significant.

The decision rule is stated thus: 
if the t-statistics is greater than or equal to the critical value of 2.048 reject the null hypothesis, otherwise accept. In like manner, in the short run, if the p-value of the t-statistics in VECM is less than $5 \%$ critical value, reject the null hypothesis, otherwise accept.

We discussed the findings of the result in order to bring out the basic information gotten from the analysis of each variable in the model estimated and to link the discussion of the findings with the existing theory on the particular research work.

The dynamics that existed in the short run with clearly specified probability values. And revealed an error correction term (ECT) of -0.512567 with a significant Pval. of 0.0001 . This means that ECM or ECT met the required conditions of being negative, fractional and statistically significant, indicating the speed of adjustment from disequilibrium to equilibrium. The result showed that the speed of adjustment (ECT) between short run dynamics and the long run adjustments is $51 \%$. The implication of this result is that its coefficients are essential conditions in order that any disequilibrium be corrected in any economy. Thus, ECM will adequately act to correct any deviations of the short run dynamics to its long-run equilibrium by $51 \%$ annually.

\section{External Debt and Domestic Private Investment}

The long run result of the VECM in table 4 indicated that external debt has negative significant impact with domestic private investment, having coefficient of -0.10931 with significant critical value of (-4.82212). This means that external debt inversely relates with domestic private investment, as such does not promote domestic private investment, though significant but in negative way. This could be attributed to investment decision could not dictated by economic reasons, like increase employment, encourage diversification, generate revenue, import substitution. The borrowing could be made for selfish reasons for public office holders which does not stimulate investment. This result is supported by the works of Onyinye (2019), Salyungu \& Felician (2019) and Ditimi \& Oluwagbenga (2017) among others and contrary to the result of Joshua (2019), Kehinde et al (2015) that showed a positive relationship of external debt and domestic private investment.

\section{Domestic Debt and Domestic Private Investment}

Domestic debt has significant negative effect on domestic private investment. This means that domestic debt does not encourage domestic private investment in Nigeria within the period of study. The reasons for such influence could be the unwillingness of financial institutions to grant credit facilities to private investment due to fear of default. Also, most of the private investors have issue of collaterization, negative credit profile which does not allow them access credit facilities, thereby reducing domestic private investment. The authors in line with this result are Salyungu \& Felician (2019), Caspah (2018), to mention but a few. The result of this research is contrary to the works of Nwaeze (2017), Joshua (2019) and Ditimi \& Oluwagbenga (2017) that asserted domestic debt has a positive impact on domestic private investment.

\section{Debt Servicing and Domestic Private Investment}

Debt servicing has a negative and insignificant impact on domestic private investment with coefficient of -0.062522 , meaning that debt servicing does not stimulate private investment. This is in line with economic assumption recalled by Cohen (1993) which suggested that, debt service payments crowd out investments in areas such as education, health and infrastructure development, which are direct as well as indirect impact on economic growth.

However, the result also revealed that interest rate and FDI have positive significant and negative significant link with domestic private investment respectively. This suggest that the prevailing interest rate is not harmful and does not discourage private investors from borrowing, implying that the crowding effect noticed in the analysis may not be associated with interest rate. The result of FDI indicated a negative effect on domestic private investment, though significant.

The causal link between public debt (Domestic and external) and domestic private investment confirmed the insignificant impact. The result revealed no clear-cut direction of causality as the probability values are insignificant.

\subsection{Implication of Results}

The implication of negative significant impact of external debt on domestic private investment is that external debt has a significant unproductive influence on domestic private investment, as such most borrowed fund are not invested in choice investment. This diversion decreases the production capacity of the domestic private investors, which should stimulate increase in the overall productivity of the economy for better living.

Domestic debt having negative significant influence on domestic private investment implies that sourcing fund for private investment is compromised by high level of government involvement in loanable fund. Therefore, leaving the private investment to crumble or not even emerge. Another implication is on the burden of debt servicing. It is an established fact that when domestic debt increases it places burden on the populace inform of tax payment, which creates a dis-incentive to work as a sizeable proportion of the extra income that would be taxed away.

The negative and insignificant impact of debt servicing on domestic private investment implies that the fund that could be used for investment is usually channeled to servicing debt, as such, reducing available fund for investment. The implication of positive significant interest rate with statistical significance of $5.29591>2.048$ is that there would be scarcity of or unavailability of loanable fund for private investments, thereby pushes the private investors to a tight corner or better 
still, unattainable point to accessing credit facilities or emerge. Result of FDI implies that FDI contributed to the crowding out of domestic private investment noticed in the analysis with increased capacity that outweighed the domestic private investments.

Causality result implied that public debt variables work independent of domestic private investment.

Based on findings, the study recommends that;

1. Debt management office should review its credit policies in favour of the private sector. For instance, $\mathrm{CBN}$ should dedicate certain percent of portfolio to private sector.

2. DMO to put up strategies like renegotiate debt, avoid increase in borrowing, offset debt just to address debt servicing and reduce pressure on economic operations.

3. Economic manager to adopt discretion approach to manage public debt and private investment issues

4. Government should ensure sustainable debt that will encourage economic growth, fiscal consolidation, a policy mix that supports growth and timely diversification of the economy with judicious use of borrowed funds.

5. All foreign direct investments should be directed to critical sectors of the economy, like, Agriculture, solid mineral sector etc.

From the empirical results, the researcher concluded that public debt crowds out domestic private investment in the long run in Nigeria within the period of the study.

\section{SUGGESTION FOR FURTHER STUDY}

There is need for further study to verify whether the debt servicing expenses will deter mainly on internal or external investment.

\section{REFERENCES}

[1] Adam Smith (1776). 'An Enquiry into the Nature, Cause of the Wealth of Nature", p. 410

[2] Adetokunbo A. M., Ebere C. E. (2019). Determinants and analysis of domestic debt in Nigeria: 1970- 2015. Acta Universitatis Danubius, Economica 15(2), Pp. 275-287 (2019).

[3] Bista, N. B. (2013). Government domestic borrowing and private investment in Nepal. International Journal of Economic Sciences, II(2), 28-42.

[4] Bonga, W. G., Chirowa, F. \& Nyamapfeni, J. (2015). Growth-debt nexus: An examination of public debt levels and debt crisis in Zimbabwe. Journal of Economics and Finance (IOSR-JEF), 6(2). Pp. 9-14.

[5] Charles O, \& Abimbola O (2018). The impact of external debt on: the Nigerian Economy. Journal of Economics International and Business Management 6(2): 30-39.

[6] Caspah, L. (2018). Effects of government borrowing on private investments in Kenya. Journal of Finance and Economics, 6(2): pp 49-59.

[7] Clements, B., Bhattarharya. R. and Nguyen. T.Q. (2003). External debt, public investment and growth in low income countries. IMF Working Paper No 03/249.

[8] CBN (2015). Central Bank of Nigeria Statistical Bulletin, 26, Pp 1 $-23$
[9] CBN (2017). Central Bank of Nigeria Statistical Bulletin, 28, Pp 1 $-28$

[10] Cohen, D. (1993). Low investment and large LDC debt in the 1980's. The American Economic Review, 83(3), 437-449.

[11] Debt Management Office (2016). Annual Report and Statement of Accounts.

[12] Debt Management Office (2017). Federal government domestic debt outstanding by instruments. June, Abuja Nigeria. Retrieved from www.Dmo.Gov.Ng

[13] Ezema, C. A., Nwekwo, N. M., \& Agbaji, B. C. (2018). Impact of external debt and its services burden to economic growth in Africa: Econometric evidence from Nigeria 1990-2016. International Journal of Academic Research in Economics and Management Sciences, 7(3), pp 232-250.

[14] Granger C. W. J. (1969). Investigating causal relations by econometric models and cross-Spectral Methods. Econometrica, 37(3), Pp. 424-438, 1969.

[15] Hansen, H. A. (1941). "Fiscal Policy and Business Cycle", p-152161 ,

[16] Harold G. Moulton, (1943); The New Philosophy of Public Debt, p. 45

[17] Harold M. Groves, Financing Government (1958). p. 580

[18] Inimino, E. E., Abuo, M. A., \& Bosco, I. E. (2018). Interest rate and domestic private investment in Nigeria. International Journal of Research and Innovation in Social Science (IJRISS) II(X), Pp $198-206$.

[19] Joshua A. Ogunjimi (2019). The impact of public debt on investment: Evidence from Nigeria. Development Bank of Nigeria. Journal of Economics \& Sustainable Growth, Pp 1-29

[20] Kalu E. O. (2015). Response of foreign private investment to public debt in Nigeria. Romanian Economic Journal, 18(56), Pp 65-86.

[21] Kehinde J. A., Olanike B., Oni E., Achukwu M. (2015). Public debt and private investment inNigeria. American Journal of Economics 2015, 5(5):pp. 501-507

[22] Keynes, J. M. (1936). The general theory of employment, interest and money. Cambridge University Press

[23] Krugman, P. (1988). Financing versus forgiving a debt overhang. Journal of Development Economics, 29, Pp. 253-68.

[24] Murungi, S. M \& Okiro K. (2018). Impact of government debt on economic growth in Kenya: A Critical Literature Review. European Scientific Journal, 14 (1), Pp 240 - 257

[25] Myers, S. (1977). Determinants of corporate borrowing. Journal of Financial Economics, 5 (2): pp. 147-175.

[26] Nwaeze C. N. (2017). Public borrowing and private investment in Nigeria: Any crowding out effect? Jorind 15(2) December, 2017, Pp 24 - 34

[27] Ncanywa, T. \& Masoga, M. M. (2018). Can public debt stimulate public investment and economic growth in South Africa? Cogent Economics \& Finance, 6(1),Pp 1-13

[28] Oluwafadekemi A. \& Adeyemi A. O. (2018). Fiscal deficit and economic growth in Nigeria: Ascertaining a feasible threshold. International Journal of Economics and Financial Issues, Econjournals, 8(3), Pp 296-306.

[29] Onakoya, A. B. \& Ogunade, A. O. (2017). External debt and Nigerian economic growth connection: Evidence from Autoregressive Distributed Lag Approach. Journal of Economics and Development Studies,5(1), Pp. 66-78

[30] Phillip A., Victoria S., Md Azharu I., Omankhanlen A.E., Oluwaseun A. \& Temioluwa O. (2017).

[31] The impact of domestic debt on private credits in Nigeria: A structural VAR Approach, (1981-2015). Research \& Reviews: Journal of Social Sciences RRJSS, 3(1), Pp. 64 - 72.

[32] Rana E. A \& Abid R. G. (2009). Crowding out effect of public borrowing: A case of Pakistan.

[33] MPRA Paper No. 16292 Presented in 8th National Research Conference on Management and Computer Sciences. 29th January 2009 At Szabist Islamabad, Pakistan.

[34] Robert King'wara (2014). The impact of domestic public debt on private investment in Kenya. Developing Country Studies, 4(22), Pp 88-96 
[35] Rostow, W. W. (1960). The five stages of growth - a Summary. The Stages of economic growth: A Non-Communist Manifesto. Cambridge: Cambridge University Press. Pp. 4-16. Archived from the Original on 23 - 02 - 2013.

[36] Salama, Y. \& Aziza, O. S. (2018). Public debt and economic growth: Evidence from Tanzania.

[37] Journal of Economics, Management and Trade 21(7), 1-12.
[38] Sulaiman, L.A. \& Azeez, B.A. (2012). Effect of external debt on economic growth of Nigeria. Journal of Economic and Sustainable Development, 3(8).

[39] Thilanka, H.R.A.C., Sri Ranjith, J.G. (2018). The impact of public debt on private investment: Sri Lankan Experience. International Journal of Business and Social Research, 8(8): pp 01-10 